\title{
Methylation-associated silencing of SFRP1 in renal cell carcinoma
}

\author{
YASUO AWAKURA, EIJIRO NAKAMURA, NORIYUKI ITO, TOSHIYUKI KAMOTO and OSAMU OGAWA \\ Department of Urology, Kyoto University Graduate School of Medicine, Kyoto, Japan
}

Received March 12, 2008; Accepted June 21, 2008

DOI: $10.3892 /$ or_00000138

\begin{abstract}
Secreted frizzled-related protein 1 (SFRP1) is a candidate tumor suppressor gene located at 8p11.2 and antagonizes the Wnt signaling pathway. Epigenetic inactivation of SFRP1 by methylation of its promoter $\mathrm{CpG}$ island has recently been reported in several types of cancers. In the present study, we examined the expression and methylation status of SFRP1 in renal cell carcinoma (RCC). Three RCC cell lines were tested and none expressed the SFRP1 transcript. Bisulfite sequencing of the SFRP1 promoter and treatment of the RCC cell lines with 5-aza-2'deoxycytidine and/or trichostatin A revealed the association between SFRP1 expression and promoter hypermethylation. Methylation-specific PCR detected hypermethylation in 26/57 (45.6\%) conventional RCC cases and 2/8 (25\%) papillary RCC cases. Quantitative real-time PCR showed $>3$-fold decrease of SFRP1 expression in 33/34 (97.1\%) conventional RCC cases. Microsatellite analysis showed loss of heterozygosity at the SFRP1 locus (D8S1180) in only 3/28 $(10.7 \%)$ conventional RCC cases. The present findings indicate that methylation-associated silencing of SFRP1 frequently occurs in RCC and plays a pivotal role in early carcinogenesis. However, previous immunohistochemical studies on B-catenin have suggested that activation of the canonical Wnt pathway through $\beta$-catenin stabilization is infrequent in RCC. Thus, further basic studies are required to elucidate how the loss of SFRP1 activity contributes to the Wnt and other signaling pathways in RCC.
\end{abstract}

\section{Introduction}

Renal cell carcinoma (RCC) comprises of a heterogeneous group of tumors and is classified into various subtypes according to not only morphological features but also commonly observed genetic abnormalities (1). Conventional RCC is the major subtype of RCC and accounts for $~ 75 \%$ of kidney cancers: its development involves the accumulation of multiple chromosome deletion at $3 \mathrm{p}, 6 \mathrm{q}, 8 \mathrm{p}, 9 \mathrm{p}$ and $14 \mathrm{q}$.

Correspondence to: Dr Osamu Ogawa, Department of Urology, Kyoto University Graduate School of Medicine, 54 Kawahara-cho, Shogoin, Sakyo-ku, Kyoto 606-8507, Japan

E-mail: ogawao@kuhp.kyoto-u.ac.jp

Key words: DNA methylation, renal cell carcinoma, secreted frizzled-related protein 1
Of these changes, loss of heterozygosity $(\mathrm{LOH})$ at $3 p$ is an early genetic change. The Von Hippel-Lindau gene is a tumor suppressor gene located at 3 p.25 and its inactivation by mutation and hypermethylation has been reported in up to 57 and $19 \%$ of conventional RCCs, respectively (2). Additionally, $\mathrm{LOH}$ at $8 \mathrm{p}$ has been identified in $15-50 \%$ (3-5) and in particular, $8 \mathrm{p} 21.1$ deletions have been reported to be associated with tumor grade (5). Allelic loss of $8 p$ is also a frequent genetic event in other types of cancers, suggesting the presence of one or more tumor suppressor genes on this chromosome arm (3).

Secreted frizzled-related protein 1 (SFRP1) is one of the candidate tumor suppressor genes located at 8p11.2 (6). SFRPs are extracellular signaling molecules that antagonize the Wnt signaling pathway: aberrations in this pathway are known to play a pivotal role in cancer development. Among members of the SFRP family, SFRP1 protein is expressed in the tubular cells of the normal kidney (7), which is the possible origin of RCC (1). A recent in vitro study showed that ectopic SFRP1 expression in SFRP1-deficient cancer cell lines attenuates Wnt signaling and induces apoptosis (8). In addition, epigenetic inactivation of SFRP1 by promoter hypermethylation has been reported in several types of cancers (6,9-11). Herein, we examined the expression and methylation status of SFRP1 in RCC and correlated the findings with clinical/pathological factors.

\section{Materials and methods}

Clinical samples. We obtained 65 tumor specimens and 22 corresponding normal renal tissues from 57 patients with conventional RCC and 8 patients with papillary RCC who had undergone surgery at Kyoto University Hospital. The tumors were staged and graded according to the International TNM classification system and the Fuhrman grading system, respectively $(12,13)$. Each tissue specimen was snap-frozen immediately after surgical resection and was kept at $-80^{\circ} \mathrm{C}$ until DNA/RNA extraction. As controls for microsatellite analysis, peripheral blood leukocytes (PBLs) were collected from 33 patients with conventional RCC. Informed consent was obtained from all patients. The Institutional Review Board of the Kyoto University Graduate School of Medicine approved the present study.

Cell lines. Caki-1 and ACHN were purchased from American Type Culture Collection (Manassas, VA). NC65 was kindly donated by Dr F.H. Schroder (Erasmus University MC Rotterdam, The Netherlands) (14). These cell lines were derived from conventional RCC. All cell lines were maintained 
in RPMI-1640 medium (Life Technologies, Inc., Rockville, MD) containing $10 \%$ fetal bovine serum.

$R N A$ isolation and reverse transcription- $P C R(R T-P C R)$. Total RNA was isolated using RNeasy kit and RNase-Free DNase (Qiagen, Valencia, CA) according to the manufacturer's protocol. RNA integrity was verified by using the Agilent Bioanalyzer (Agilent Technologies, Palo Alto, CA). Reverse transcription was performed using $3 \mu \mathrm{g}$ of total RNA and First-Strand cDNA synthesis kit (Amersham Biosciences, Piscataway, NJ). The primer sequences used were 5'-CTC AAC AAG AAC TGC CAC GC-3' and 5'-TTC ATC CTC AGT GCA AAC TCG-3' for SFRP1 and 5'-TAC CTG GTT GAT CCT GCC AGT-3' and 5'-ATC TAG AGT CAC CAA AGC CGC-3' for $18 \mathrm{~S}$ rRNA.

Quantitative real-time PCR. For quantitative real-time PCR assay, QuantiTect SYBR-Green PCR kit (Qiagen) and GenAmp 5700 sequence detection system (Applied Biosystems, Foster, CA) were used according to the manufacturers' instructions. The PCR conditions were as follows: $95^{\circ} \mathrm{C}$ for $15 \mathrm{~min}$, followed by 40 cycles of $94^{\circ} \mathrm{C}$ for $15 \mathrm{sec}, 60^{\circ} \mathrm{C}$ for $30 \mathrm{sec}$ and $72^{\circ} \mathrm{C}$ for $30 \mathrm{sec}$. To verify that the primer pair used produced only a single band, a dissociation protocol was included after cycling and the dissociation of the PCR products was determined from $60^{\circ} \mathrm{C}$ to $95^{\circ} \mathrm{C}$. The assay included a no-template control, a standard curve of 5 serial dilution points (in steps of 5- or 10-fold) of a control cDNA, and each of the test cDNAs. For each sample, the experiment was performed in duplicate and the mean $\mathrm{Ct}$ value was calculated. The gene expression level was calculated, as described previously (15). A cDNA sample pool of normal kidney tissue, derived from the specimens of 5 cases, was used as calibrator sample. The reference gene was that encoding TATA-binding protein (TBP). The primer sequences used were 5'-TCC CTG TGA CAA CGA GTT GAA A-3' and 5'-GGA CAA TCT TCT TGT CGC CAT T-3' for SFRP1 and 5'-CCC GAA ACG CCG AAT ATA AT-3' and 5'-CAC ACC ATT TTC CCA GAA CTG A-3' for TBP.

Demethylation and inhibition of histone deacetylation. The 3 RCC cell lines (ACHN, Caki-1 and NC65) were split to low density in 10-cm dishes and grown for $24 \mathrm{~h}$. They were then treated with (i) 5-aza-2'-deoxycytidine (DAC; $10 \mu \mathrm{M}$; Sigma, St. Louis, MO) for $72 \mathrm{~h}$, (ii) DAC $(10 \mu \mathrm{M})$ for $72 \mathrm{~h}$ followed by Trichostatin A (TSA; $300 \mathrm{nM}$; Wako, Osaka, Japan) for an additional $24 \mathrm{~h}$ and (iii) TSA (300 $\mathrm{nM}$ ) for $24 \mathrm{~h}$. The medium containing DAC was changed every $24 \mathrm{~h}$.

DNA extraction, bisulfite modification and sequencing . Genomic DNA was extracted as described previously (16) or by using QIAmp DNA mini kit (Qiagen). DNA was treated with sodium bisulfite by using Epitect Bisulfite kit (Qiagen) according to the manufacturer's protocol.

For bisulfite sequencing, the bisulfite-modified DNA was amplified by PCR with the following primers that were used in a previous study (9): 5'-TGG TTT TGT TTT TTA AGG GGT GTT GAG T-3' and 5'-TCC TAC CRC AAA CTT CCA AAA ACC TCC-3'. The primers span the $429 \mathrm{bp}$ sequence around presumed transcriptional start site of SFRP1.
The amplified products were then cloned into pCR2.1 vector using TOPO TA cloning kit (Invitrogen, Carlsbad, CA). The plasmid DNA was purified using QIAprep Spin mini prep kit (Qiagen) and then sequenced using Big-Dye Terminator Cycle Sequencing Ready Reaction kit (Applied Biosystems) with an ABI PRISM 310 Genetic Analyzer (Applied Biosystems). Eight clones were sequenced for each sample.

Methylation-specific PCR (MSP). MSP was performed with the primers used in a previous study (9). The primer sequences were 5'-TGT AGT TTT CGG AGT TAG TGT CGC GC-3' and 5'-CCT ACG ATC GAA AAC GAC GCG AAC G-3' for the methylated reaction and 5'-GTT TTG TAG TTT TTG GAG TTA GTG TTG TGT-3' and 5'-CTC AAC CTA CAA TCA AAA ACA ACA CAA ACA-3' for the unmethylated reaction. The MSP conditions were as follows: denaturation at $95^{\circ} \mathrm{C}$ for $5 \mathrm{~min}, 35$ cycles of amplification $\left(95^{\circ} \mathrm{C}, 30 \mathrm{sec} ; 64^{\circ} \mathrm{C}, 30 \mathrm{sec}\right.$ and $\left.72^{\circ} \mathrm{C}, 30 \mathrm{sec}\right)$ and a final elongation step at $72^{\circ} \mathrm{C}$ for $10 \mathrm{~min}$. The PCR mixture contained 1X PCR buffer [67 mM Tris- $\mathrm{HCl}$ (pH 8.8), $16.6 \mathrm{mM}$ $\left(\mathrm{NH}_{4}\right)_{2} \mathrm{SO}_{4}, 6.7 \mathrm{mM} \mathrm{MgCl}$ and $10 \mathrm{mM}$ 3-mercaptoethanol], $0.2 \mathrm{mM}$ of deoxynucleotide triphosphate mixture, $0.5 \mu \mathrm{M}$ of each primer, 1.0 units of JumpStart RedTaq polymerase (Sigma) and $1 \mu \mathrm{l}$ of bisulfite-modified DNA in a final volume of $20 \mu 1$. The PCR products were analyzed by $3 \%$ agarose gel electrophoresis.

LOH analysis. The microsatellite marker D8S1180 was used with a fluorescence-labeled forward primer and a tailed reverse primer (Applied Biosystems). Genomic DNA extracted from normal kidney tissue or PBLs served as the normal control. The PCR products were electrophoresed on ABI 310 system and analyzed using GeneScan 3.1 software (Applied Biosystems). LOH was defined as $>40 \%$ reduction in peak intensity compared to that observed for the corresponding normal control (17).

Statistical analysis. Fisher's exact test was performed to analyze the relationship between SFRP1 methylation status and clinical/pathological factors. The Mann-Whitney U test was used to analyze the correlation of SFRP1 expression with methylation status and clinical/pathological factors. Statistical significance was defined as $\mathrm{P}<0.05$. Statistical analyses were performed using Dr SPSS II (SPSS, Chicago, IL).

\section{Results}

Re-expression of SFRP1 in RCC cell lines by demethylation and/or inhibition of histone deacetylation. None of the 3 RCC cell lines (ACHN, Caki-1 and NC65) expressed SFRP1 mRNA (Fig. 1). In ACHN, SFRP1 mRNA expression was induced after DAC or TSA treatment. In Caki-1, SFRP1 expression was restored after TSA treatment but not DAC treatment. In NC65, SFRP1 expression was detected after DAC treatment but not TSA treatment. In all the cell lines, the combination of DAC and TSA remarkably elevated the level of SFRP1 mRNA expression that had been induced by DAC or TSA.

Methylation status of SFRP1 in RCC cell lines. We analyzed the methylation status of the SFRP1 promoter in the $3 \mathrm{RCC}$ 


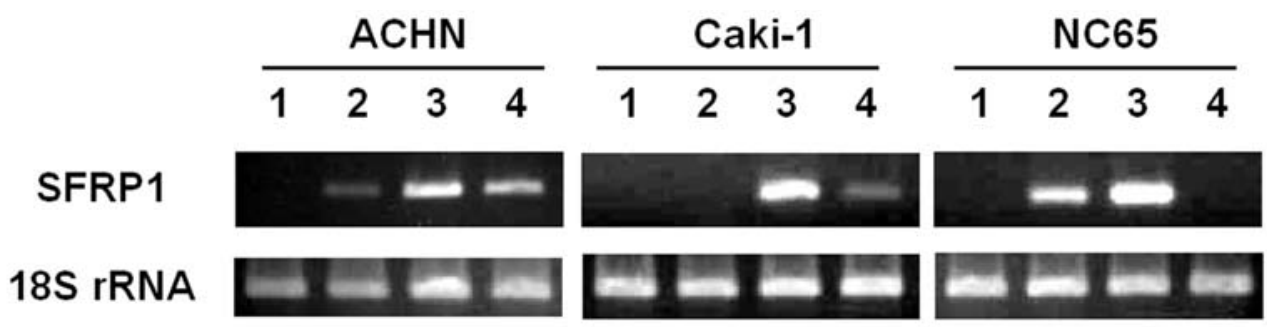

Figure 1. RT-PCR analysis of SFRP1 in RCC cell lines. The RCC cell lines were subjected to 4 different treatments: Mock (1), DAC (2), DAC + TSA (3) and TSA (4).

\section{Bisufite sequencing}

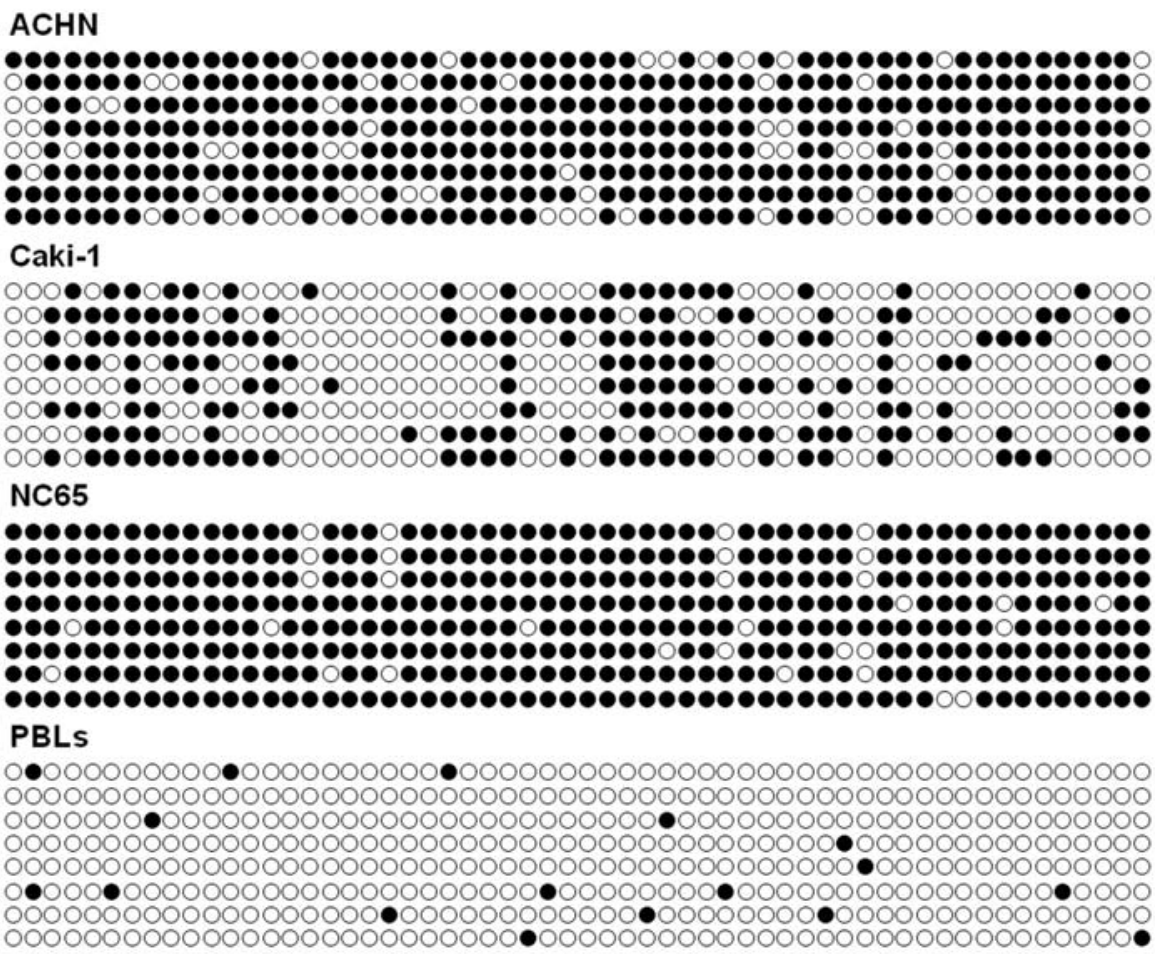

MSP
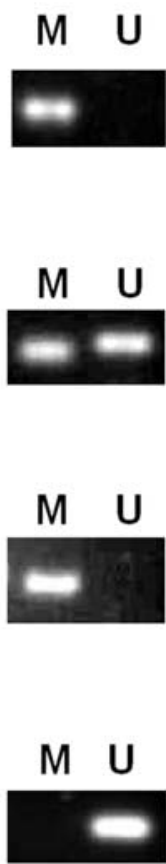

Figure 2. Bisulfite sequencing analysis of SFRP1 in the 3 RCC cell lines (ACHN, Caki-1 and NC65) and peripheral blood leukocytes (PBLs). Open and filled circles represent unmethylated and methylated $\mathrm{CpG}$ sites, respectively and each row represents a single clone. MSP results from the same samples are shown on the right. Bands in ' $\mathrm{M}$ ' lanes are PCR products for methylation-specific primers and those in ' $U$ ' lanes are PCR products for unmethylation-specific primers.

cell lines by using bisulfite sequencing and MSP (Fig. 2). Bisulfite sequencing demonstrated that almost the entire promoter region was densely methylated in all the analyzed ACHN and NC65 clones. MSP detected methylated signals but not unmethylated signals in these cell lines. In Caki-1, bisulfite sequencing showed partial methylation of the promoter region and MSP detected both methylated and unmethylated signals. Then, we examined the methylation status of SFRP1 in PBLs from a healthy individual. Bisulfite sequencing and MSP showed virtually no methylation.

Methylation status of SFRP1 in primary RCC. By using MSP, we analyzed the methylation status of the SFRP1 promoter in the 65 primary RCCs and 22 normal kidney tissues (Fig. 3). NC65 and PBLs were used as the methylated and unmethylated controls, respectively. SFRP1 was methylated in $26(45.6 \%)$ of 57 conventional RCC cases (Table I). Methylation status of SFRP1 was significantly associated with age ( $\geq 60$ vs. $<60: P=0.02)$, whereas it was not significantly related to gender, tumor stage and histological grade (gender: $\mathrm{P}=1.0,>\mathrm{T} 2$ vs. $\mathrm{T} 1$ and $\mathrm{T} 2: \mathrm{P}=0.77, \geq \mathrm{N} 1$ or $\mathrm{M} 1$ vs. N0M0: $\mathrm{P}=0.31, \mathrm{G} 1$ and $\mathrm{G} 2$ vs. $\mathrm{G} 3$ and $\mathrm{G} 4: \mathrm{P}=0.16)$. In contrast, SFRP1 was methylated in $2(25 \%)$ of 8 papillary RCC cases.

SFRP 1 expression in primary $R C C$. We analyzed the SFRP1 transcriptional levels in 34 clinical samples of conventional RCC by using quantitative real-time PCR. In 33 (97.1\%) of 34 conventional RCC samples, SFRP1 expression was down-regulated by $>3$-fold compared to that in the normal kidney tissue (Table I). The expression levels of SFRP1 were not significantly associated with SFRP1 methylation $(\mathrm{P}=0.41)$ and clinical/pathological factors $(\geq 60$ vs. <60: $\mathrm{P}=0.54$, gender: $\mathrm{P}=0.63$, > T2 vs. $\mathrm{T} 1$ and $\mathrm{T} 2$ : $\mathrm{P}=0.90$, $\geq \mathrm{N} 1$ or M1 vs. N0M0: $\mathrm{P}=0.11, \mathrm{G} 1$ and $\mathrm{G} 2$ vs. G3 and G4: $\mathrm{P}=1.0)$. 
Table I. Summary of clinical/pathological factors and SFRP1 status in RCC patients.

\begin{tabular}{|c|c|c|c|c|c|c|c|c|}
\hline \multirow[b]{2}{*}{ No. } & \multirow[b]{2}{*}{ Age } & \multirow[b]{2}{*}{ Gender } & \multirow[b]{2}{*}{ Stage } & \multirow[b]{2}{*}{ Grade } & \multicolumn{2}{|c|}{ Methylation } & \multirow[b]{2}{*}{$\mathrm{LOH}$} & \multirow[b]{2}{*}{ Expression (vs. normal) } \\
\hline & & & & & Cancer & Normal & & \\
\hline \multicolumn{9}{|c|}{ Conventional RCC } \\
\hline 1 & 62 & M & T2N0M0 & 4 & M & & NI & $5.26 \mathrm{E}-04$ \\
\hline 2 & 72 & M & T1bN0M0 & 2 & M & $\mathrm{U}$ & - & $7.02 \mathrm{E}-04$ \\
\hline 3 & 61 & $\mathrm{~F}$ & T1bN0M0 & 2 & $\mathrm{U}$ & $\mathrm{U}$ & NI & $1.14 \mathrm{E}-03$ \\
\hline 4 & 71 & M & T1bN0M0 & 3 & M & $\mathrm{U}$ & NI & $1.15 \mathrm{E}-03$ \\
\hline 5 & 71 & $\mathrm{~F}$ & T3bNOM0 & 4 & M & & - & $1.22 \mathrm{E}-03$ \\
\hline 6 & 54 & M & T1bN0M0 & 2 & $\mathrm{U}$ & & - & $1.48 \mathrm{E}-03$ \\
\hline 7 & 39 & M & T3aNOM0 & 2 & $\mathrm{U}$ & $\mathrm{U}$ & - & $1.74 \mathrm{E}-03$ \\
\hline 8 & 76 & $\mathrm{~F}$ & T3bN0M1 & 2 & M & $\mathrm{U}$ & - & $2.25 \mathrm{E}-03$ \\
\hline 9 & 66 & M & T1aN0M0 & 2 & M & & - & $2.40 \mathrm{E}-03$ \\
\hline 10 & 67 & M & T1aN0M0 & 2 & M & & NI & $2.95 \mathrm{E}-03$ \\
\hline 11 & 64 & M & T1bN0M0 & 2 & M & $\mathrm{U}$ & - & $3.30 \mathrm{E}-03$ \\
\hline 12 & 44 & M & T2N0M0 & 2 & $\mathrm{U}$ & $\mathrm{U}$ & NI & $3.35 \mathrm{E}-03$ \\
\hline 13 & 74 & $\mathrm{M}$ & T1aN0M0 & 1 & $\mathrm{U}$ & $\mathrm{U}$ & NI & $3.52 \mathrm{E}-03$ \\
\hline 14 & 60 & M & T1aN0M0 & 2 & $\mathrm{U}$ & & NI & $3.78 \mathrm{E}-03$ \\
\hline 15 & 65 & M & T1aN0M0 & 2 & $\mathrm{U}$ & & NI & $4.53 \mathrm{E}-03$ \\
\hline 16 & 64 & M & T3aN0M1 & 3 & $\mathrm{U}$ & & - & $4.75 \mathrm{E}-03$ \\
\hline 17 & 60 & M & T1aN0M0 & 2 & $\mathrm{U}$ & $\mathrm{U}$ & - & $4.85 \mathrm{E}-03$ \\
\hline 18 & 55 & M & T1bN0M0 & 2 & M & & - & 4.99E-03 \\
\hline 19 & 74 & M & T1aN0M0 & 2 & M & & - & $5.64 \mathrm{E}-03$ \\
\hline 20 & 67 & $\mathrm{~F}$ & T1bN0M0 & 2 & M & M & + & $6.97 \mathrm{E}-03$ \\
\hline 21 & 67 & M & T1aN0M0 & 1 & $\mathrm{U}$ & $\mathrm{U}$ & - & $1.03 \mathrm{E}-02$ \\
\hline 22 & 46 & M & T1aN0M0 & 2 & $\mathrm{U}$ & & NI & $1.19 \mathrm{E}-02$ \\
\hline 23 & 58 & $\mathrm{~F}$ & T2N0M1 & 2 & $\mathrm{U}$ & & NI & $1.21 \mathrm{E}-02$ \\
\hline 24 & 49 & $\mathrm{~F}$ & T1bN0M0 & 2 & $\mathrm{U}$ & & NI & $1.27 \mathrm{E}-02$ \\
\hline 25 & 60 & $\mathrm{~F}$ & T3bN0M0 & 2 & $\mathrm{U}$ & & - & $1.70 \mathrm{E}-02$ \\
\hline 26 & 63 & M & T3bN0M1 & 3 & M & & - & $3.55 \mathrm{E}-02$ \\
\hline 27 & 69 & M & T3aN0M1 & 2 & $\mathrm{U}$ & & + & 4.33E-02 \\
\hline 28 & 38 & $\mathrm{~F}$ & T1bN0M0 & 3 & $\mathrm{U}$ & $\mathrm{U}$ & NI & 8.62E-02 \\
\hline 29 & 66 & M & T3bN1N1 & 4 & M & $\mathrm{U}$ & - & 8.99E-02 \\
\hline 30 & 70 & M & T2N0M0 & 1 & M & $\mathrm{U}$ & NI & $9.04 \mathrm{E}-02$ \\
\hline 31 & 60 & M & $\mathrm{T} 2 \mathrm{~N} 2 \mathrm{M} 1$ & 4 & M & & - & $1.12 \mathrm{E}-01$ \\
\hline 32 & 74 & M & T1aN0M0 & 2 & $\mathrm{U}$ & & NI & $2.15 \mathrm{E}-01$ \\
\hline 33 & 65 & M & T1aN0M0 & 2 & M & $\mathrm{U}$ & NI & $2.96 \mathrm{E}-01$ \\
\hline 34 & 67 & $\mathrm{~F}$ & T1aN0M0 & 2 & $\mathrm{U}$ & & NI & $1.18 \mathrm{E}+00$ \\
\hline 35 & 73 & $\mathrm{~F}$ & T1bN0M0 & 2 & M & M & NI & \\
\hline 36 & 72 & M & T1aN0M0 & 1 & $\mathrm{U}$ & $\mathrm{U}$ & - & \\
\hline 37 & 63 & M & T1aN0M0 & 2 & $\mathrm{U}$ & $\mathrm{U}$ & - & \\
\hline 38 & 37 & M & T2N0M0 & 1 & M & $\mathrm{U}$ & - & \\
\hline 39 & 76 & $\mathrm{~F}$ & T1aN0M0 & 1 & $\mathrm{U}$ & $\mathrm{U}$ & - & \\
\hline 40 & 69 & M & T3aN0M0 & 2 & $\mathrm{U}$ & $\mathrm{U}$ & NI & \\
\hline 41 & 67 & $\mathrm{~F}$ & T3aN0M0 & 2 & $\mathrm{U}$ & $\mathrm{U}$ & - & \\
\hline 42 & 61 & M & T3aNOM0 & 2 & $\mathrm{U}$ & & $\mathrm{N}$ & \\
\hline 43 & 69 & M & T3aN0M1 & 2 & M & & NI & \\
\hline 44 & 61 & M & T1bN0M0 & 3 & $\mathrm{U}$ & & NI & \\
\hline 45 & 64 & $\mathrm{~F}$ & T2N0M0 & 2 & M & & + & \\
\hline 46 & 64 & M & T1aN0M0 & 2 & M & & ND & \\
\hline 47 & 74 & $\mathrm{~F}$ & T2N0M0 & 3 & M & & NI & \\
\hline 48 & 32 & M & T2N0M0 & 1 & $\mathrm{U}$ & & - & \\
\hline 49 & 84 & $\mathrm{~F}$ & T1aN0M0 & 2 & M & & NI & \\
\hline 50 & 60 & M & T3bNOM0 & 2 & M & & - & \\
\hline
\end{tabular}


Table I. Continued.

\begin{tabular}{|c|c|c|c|c|c|c|c|c|}
\hline \multirow[b]{2}{*}{ No. } & \multirow[b]{2}{*}{ Age } & \multirow[b]{2}{*}{ Gender } & \multirow[b]{2}{*}{ Stage } & \multirow[b]{2}{*}{ Grade } & \multicolumn{2}{|c|}{ Methylation } & \multirow[b]{2}{*}{$\mathrm{LOH}$} & \multirow[b]{2}{*}{ Expression (vs. normal) } \\
\hline & & & & & Cancer & Normal & & \\
\hline \multicolumn{9}{|c|}{ Conventional RCC } \\
\hline 51 & 64 & M & T3bN0M0 & 2 & $\mathrm{U}$ & & - & \\
\hline 52 & 47 & M & T3aN0M0 & 2 & $\mathrm{U}$ & & NI & \\
\hline 53 & 55 & $\mathrm{~F}$ & T1aN0M0 & 2 & $\mathrm{U}$ & & ND & \\
\hline 54 & 68 & M & T1bN0M0 & 2 & $\mathrm{U}$ & & - & \\
\hline 55 & 70 & M & T3aN0M1 & 2 & M & & - & \\
\hline 56 & 59 & M & T3bN0M1 & 2 & $\mathrm{U}$ & & NI & \\
\hline 57 & 65 & M & T2N0M1 & 2 & M & & NI & \\
\hline \multicolumn{9}{|c|}{ Papillary RCC } \\
\hline 1 & 72 & M & T1bN0M0 & 2 & $\mathrm{U}$ & & & \\
\hline 2 & 53 & M & T1aN0M0 & 2 & $\mathrm{U}$ & & & \\
\hline 3 & 67 & $\mathrm{~F}$ & T1bN0M0 & 3 & M & & & \\
\hline 4 & 75 & M & T3aN1M1 & 2 & $\mathrm{U}$ & & & \\
\hline 5 & 57 & M & T1bN0M0 & 2 & $\mathrm{U}$ & & & \\
\hline 6 & 79 & M & T1aN0M0 & 2 & $\mathrm{U}$ & & & \\
\hline 7 & 74 & M & T1aN0M0 & 2 & M & & & \\
\hline 8 & 76 & M & T1aN0M0 & 1 & $\mathrm{U}$ & & & \\
\hline
\end{tabular}

M, methylated; U, unmethylated; NI, not informative and ND, not determined.

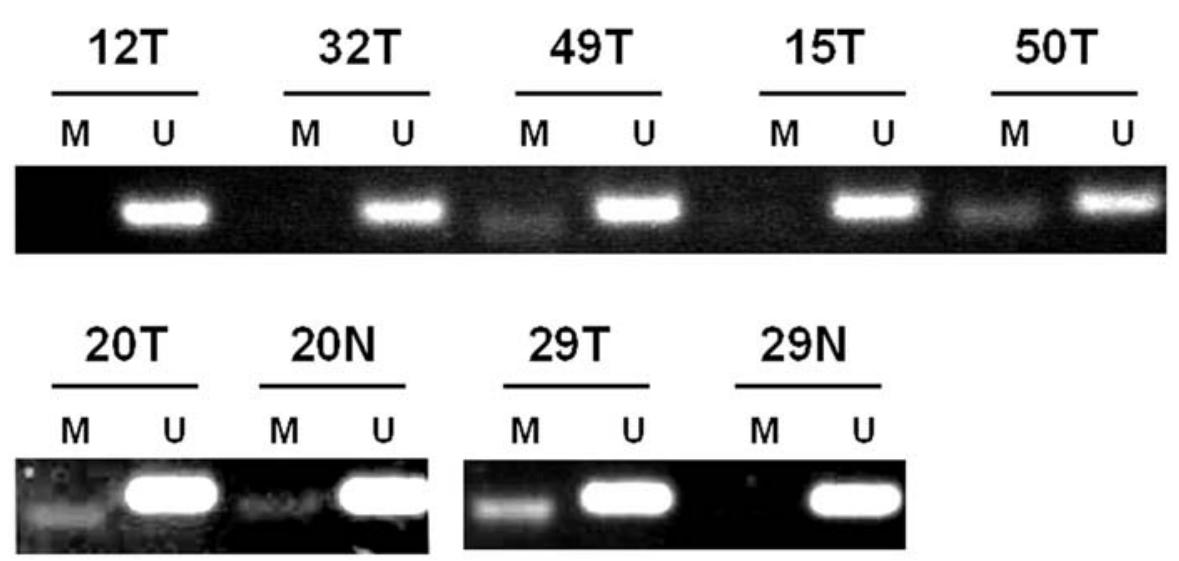

Figure 3. MSP analysis of SFRP1 in primary conventional RCC. The number corresponds to that in Table I. T and N denote tumor and normal kidney, respectively. Bands in the ' $M$ ' and ' $U$ ' lanes are as indicated in Fig. 2.

Analysis of LOH at D8S1180. To determine whether primary RCC shows allelic loss of the SFRP1 locus, we performed LOH analysis by using the microsatellite marker D8S1180, which is located only $6 \mathrm{kbp}$ telomeric to the SFRP1 gene. Among 28 informative cases of the 55 conventional RCC specimens, only $3(10.7 \%)$ samples showed allelic loss of D8S1180 (Table I).

\section{Discussion}

Hypermethylation in the CpG island of the SFRP1 promoter has recently been reported in several types of cancers including those of colon $(6,9)$, lungs (10) and ovaries (11).
Here, we detected SFRP1 methylation in $26(45.6 \%)$ of the 57 conventional RCC samples. While our study was in preparation, three groups reported frequent SFRP1 methylation (46.8-80\%) in clinical RCC samples (18-20), which is consistent with the current result. In the present study, SFRP1 was remarkably down-regulated in most of the conventional RCC samples, irrespective of the SFRP1 methylation status. Additionally, Dahl et al showed the frequent reduction of SFRP1 expression in the SFRP1 unmethylated samples although SFRP1 methylation status was significantly associated with mRNA expression in their study $(\mathrm{P}=0.048)$ (19). There could be several reasons underlying these findings. The samples were split for DNA and RNA extractions. Thus, 
heterogeneity in the samples may cause these findings. Then the samples contained both cancer cells and other cell types, which may have hindered the detection of SFRP1 methylation. Furthermore, not only promoter hypermethylation but also histone modification plays a critical role in epigenetic silencing. Zhao et al demonstrated that $\mathrm{O}^{6}$-methylguanineDNA methyltransferase, essential for DNA repair, is epigenetically silenced without hypermethylation in several cancer cell lines (21). In the present study, Caki-1, an SFRP1 non-expressed cell line, re-expressed SFRP1 mRNA not by DAC treatment but by TSA treatment and the $\mathrm{CpG}$ island of SFRP1 promoter in Caki-1 was not densely methylated. Thus, in some cases of conventional RCC, SFRP1 may be epigenetically silenced by histone modification without promoter hypermethylation.

The present study showed that the methylation status of SFRP1 was significantly associated with age. Although this finding needs to be confirmed in further studies, aging may have some influence on the process of SFRP1 epigenetic inactivation in RCC.

Previous studies demonstrated SFRP1 methylation in some of the normal tissues from colon carcinomas $(6,9)$. We also detected SFRP1 methylation in 2 out of 22 normal kidneys from RCC patients. Given that SFRP1 expression was remarkably reduced in the majority of the RCC specimens, this finding suggests that the epigenetic silencing of SFRP1 is an early event in RCC carcinogenesis.

LOH at 8 p 12-22 has been detected in $15-50 \%$ of conventional RCC cases (3-5). In the present study, allelic loss of the SFRP1 locus (8p11.2) was infrequently observed $(10.7 \%)$. Gene deletion may not be important in the reduction of SFRP1 expression. Furthermore, we detected SFRP1 methylation in 2 out of 8 papillary RCC cases. Recently, Yamazaki et al identified SFRP1 as the gene that is commonly down-regulated in conventional, papillary and chromophobe RCCs by using cDNA microarray (22). Thus, the epigenetic inactivation of SFRP1 might be a common phenomenon in the 3 types of RCC.

Signals of the Wnt pathway are transduced by Wnt ligands through frizzled $(\mathrm{Fz})$ membrane receptors. SFRPs attenuate these signals by competing with Fzs for Wnt ligands or by directly associating with Fzs. On binding to the Fz receptors, Wnt ligands can activate the canonical or non-canonical Wnt pathway (6). The canonical Wnt pathway operates via stabilization and increased transcriptional activity of $\beta$-catenin. However, immunohistochemical studies on $\beta$-catenin have shown that activation of the Wnt signal through $\beta$-catenin is not a significant event in RCC $(23,24)$. On the other hand, the non-canonical Wnt pathway can activate the c-Jun N-terminal kinase. Oya et al suggested that c-jun activation is relevant to early RCC carcinogenesis (25). In addition, the Wnt signal has been reported to activate the extracellular signal regulatedkinase (ERK) pathway in either a ß-catenin-dependent or -independent manner (26). Previously, our group showed that ERKs are frequently activated in RCC (27). Thus, the downregulation of SFRP1 in RCC may contribute to the activation of the non-canonical Wnt and ERK pathways rather than the canonical Wnt pathway. Further basic studies are required to evaluate the contribution of SFRP1 inactivation to the Wnt and ERK pathways in RCC.

\section{Acknowledgements}

This study was supported by a grant from the Ministry of Education, Culture, Sports, Science and Technology, Japan.

\section{References}

1. Bodmer D, van den Hurk W, van Groningen JJ, Eleveld MJ, Martens GJ, Weterman MA and van Kessel AG: Understanding familial and non-familial renal cell cancer. Hum Mol Genet 11: 2489-2498, 2002.

2. Kondo K, Yao M, Yoshida M, Kishida T, Shuin T, Miura T, Moriyama M, Kobayashi K, Sakai N, Kaneko S, Kawakami S, Baba M, Nakaigawa N, Nagashima Y, Nakatani Y and Hosaka M: Comprehensive mutational analysis of the VHL gene in sporadic renal cell carcinoma: relationship to clinicopathological parameters. Genes Chromosomes Cancer 34: 58-68, 2002.

3. Schullerus D, von Knobloch R, Chudek J, Herbers J and Kovacs G: Microsatellite analysis reveals deletion of a large region at chromosome $8 \mathrm{p}$ in conventional renal cell carcinoma. Int J Cancer 80: 22-24, 1999.

4. Hatano N, Nishikawa NS, McElgunn C, Sarkar S, Ozawa K, Shibanaka Y, Nakajima M, Gohiji K and Kiyama R: A comprehensive analysis of loss of heterozygosity caused by hemizygous deletions in renal cell carcinoma using a subtraction library. Mol Carcinog 31: 161-170, 2001.

5. Yamaguchi S, Yoshihiro S, Matsuyama H, Nagao K, Fukunaga $\mathrm{K}$, Matsumoto $\mathrm{H}$, Matsuda $\mathrm{K}$, Oba $\mathrm{K}$ and Naito $\mathrm{K}$ : The allelic loss of chromosome $3 \mathrm{p} 25$ with c-myc gain is related to the development of clear-cell renal cell carcinoma. Clin Genet 63: 184-191, 2003.

6. Caldwell GM, Jones C, Gensberg K, Jan S, Hardy RG, Byrd P, Chughtai S, Wallis Y, Matthews GM and Morton DG: The Wnt antagonist sFRP1 in colorectal tumorigenesis. Cancer Res 64: 883-888, 2004.

7. Higgins JP, Wang L, Kambham N, Montgomery K, Mason V, Vogelmann SU, Lemley KV, Brown PO, Brooks JD and van de Rijn M: Gene expression in the normal adult human kidney assessed by complementary DNA microarray. Mol Biol Cell 15: 649-656, 2004.

8. Suzuki H, Watkins DN, Jair KW, Schuebel KE, Markowitz SD, Chen WD, Pretlow TP, Yang B, Akiyama Y, Van Engeland M, Toyota M, Tokino T, Hinoda Y, Imai K, Herman JG and Baylin SB: Epigenetic inactivation of SFRP genes allows constitutive WNT signaling in colorectal cancer. Nat Genet 36 : 417-422, 2004.

9. Suzuki H, Gabrielson E, Chen W, Anbazhagan R, van Engeland M, Weijenberg MP, Herman JG and Baylin SB: A genomic screen for genes upregulated by demethylation and histone deacetylase inhibition in human colorectal cancer. Nat Genet 31: 141-149, 2002.

10. Fukui T, Kondo M, Ito G, Maeda O, Sato N, Yoshioka H, Yokoi K, Ueda Y, Shimokata K and Sekido Y: Transcriptional silencing of secreted frizzled related protein 1 (SFRP 1) by promoter hypermethylation in non-small-cell lung cancer. Oncogene 24: 6323-6327, 2005.

11. Takada T, Yagi Y, Maekita T, Imura M, Nakagawa S, Tsao SW, Miyamoto K, Yoshino O, Yasugi T, Taketani Y and Ushijima T: Methylation-associated silencing of the Wnt antagonist SFRP1 gene in human ovarian cancers. Cancer Sci 95: 741-744, 2004.

12. Sobin L and Wittekind CH: International Union Against Cancer (UICC). In: TNM Classification of Malignant Tumours, 6th edition, Wiley-Liss, New York, 2002.

13. Goldstein NS: Grading of renal cell carcinoma. Urol Clin North Am 26: 637-642, 1999.

14. Hoehn W and Schroeder FH: Renal cell carcinoma: two new cell lines and a serially transplantable nude mouse tumor (NC 65). Preliminary report. Invest Urol 16: 106-112, 1978.

15. Bieche I, Laurendeau I, Tozlu S, Olivi M, Vidaud D, Lidereau R and Vidaud M: Quantitation of MYC gene expression in sporadic breast tumors with a real-time reverse transcription-PCR assay. Cancer Res 59: 2759-2765, 1999.

16. Ozdemir E, Kakehi Y, Nakamura E, Kinoshita H, Terachi T, Okada Y and Yoshida O: HLA-DRB1*0101 and *0405 as protective alleles in Japanese patients with renal cell carcinoma. Cancer Res 57: 742-746, 1997.

17. Tomlinson IP, Lambros MB and Roylance RR: Loss of heterozygosity analysis: practically and conceptually flawed? Genes Chromosomes Cancer 34: 349-353, 2002. 
18. Urakami S, Shiina H, Enokida H, Hirata H, Kawamoto K, Kawakami T, Kikuno N, Tanaka Y, Majid S, Nakagawa M, Igawa $\mathrm{M}$ and Dahiya R: Wnt antagonist family genes as biomarkers for diagnosis, staging, and prognosis of renal cell carcinoma using tumor and serum DNA. Clin Cancer Res 12: 6989-6997, 2006.

19. Dahl E, Wiesmann F, Woenckhaus M, Stoehr R, Wild PJ, Veeck J, Knuchel R, Klopocki E, Sauter G, Simon R, Wieland WF, Walter B, Denzinger S, Hartmann A and Hammerschmied CG: Frequent loss of SFRP1 expression in multiple human solid tumours: association with aberrant promoter methylation in renal cell carcinoma. Oncogene 26: 5680-5691, 2007.

20. Gumz ML, Zou H, Kreinest PA, Childs AC, Belmonte LS, LeGrand SN, Wu KJ, Luxon BA, Sinha M, Parker AS, Sun LZ, Ahlquist DA, Wood CG and Copland JA: Secreted frizzledrelated protein 1 loss contributes to tumor phenotype of clear cell renal cell carcinoma. Clin Cancer Res 13: 4740-4749, 2007.

21. Zhao W, Soejima H, Higashimoto K, Nakagawachi T, Urano T, Kudo S, Matsukura S, Matsuo S, Joh K and Mukai T: The essential role of histone H3 Lys9 di-methylation and MeCP2 binding in MGMT silencing with poor DNA methylation of the promoter CpG island. J Biochem (Tokyo) 137: 431-440, 2005.
22. Yamazaki K, Sakamoto M, Ohta T, Kanai Y, Ohki M and Hirohashi S: Overexpression of KIT in chromophobe renal cell carcinoma. Oncogene 22: 847-852, 2003.

23. Bilim V, Kawasaki T, Katagiri A, Wakatsuki S, Takahashi K and Tomita Y: Altered expression of beta-catenin in renal cell cancer and transitional cell cancer with the absence of betacatenin gene mutations. Clin Cancer Res 6: 460-466, 2000.

24. Zhu X, Kanai Y, Saito A, Kondo Y and Hirohashi S: Aberrant expression of beta-catenin and mutation of exon 3 of the betacatenin gene in renal and urothelial carcinomas. Pathol Int 50: 945-952, 2000.

25. Oya M, Mikami S, Mizuno R, Marumo K, Mukai M and Murai M: C-jun activation in acquired cystic kidney disease and renal cell carcinoma. J Urol 174: 726-730, 2005.

26. Yun MS, Kim SE, Jeon SH, Lee JS and Choi KY: Both ERK and $\mathrm{Wnt} /$ beta-catenin pathways are involved in Wnt3a-induced proliferation. J Cell Sci 118: 313-322, 2005.

27. Oka H, Chatani Y, Hoshino R, Ogawa O, Kakehi Y, Terachi T, Okada Y, Kawaichi M, Kohno M and Yoshida O: Constitutive activation of mitogen-activated protein (MAP) kinases in human renal cell carcinoma. Cancer Res 55: 4182-4187, 1995. 